\title{
PERKEMBANGAN BUNGA DAN BUAH PIRDOT (Saurauia bracteosa DC.) DI ARBORETUM AEK NAULI
}

\author{
Flower and Fruit Development of Pirdot (Saurauia bracteosa DC.) at Aek Nauli Arboretum
}

\author{
Cica Ali ${ }^{1}$ dan/and Aam Aminah ${ }^{2}$ \\ ${ }^{1}$ Balai Litbang Lingkungan Hidup dan Kehutanan Aek Nauli \\ Jl. Raya Parapat KM 10,5 Desa Sibaganding, Parapat, Sumatera Utara, Indonesia \\ ${ }^{2}$ Balai Penelitian Teknologi Perbenihan Tanaman Hutan \\ Jl. Pakuan, Ciheuleut Kotak Pos 105 Bogor, Jawa Barat, Indonesia \\ Email: nurshabrina@yahoo.com; aamaminah515@yahoo.com
}

Tanggal diterima: 31 Agustus 2016; Tanggal direvisi: 21 Desember 2017;

Tanggal disetujui: 24 Desember 2017

\begin{abstract}
Saurauia bracteosa $D C$ is a potential plant for tumor and cancer medicine, but information about the reproductive system is currently unknown. The purpose of this study was to determine the development phases of $\underline{\mathrm{S}}$. bracteosa flower and fruit. The study was conducted by observing structural characteristics of flower and development stages from flower until ripe fruit. Phenology of flower and fruit development were classified into five stages namely flower initiation, small bud stage, large bud stage, anthesis, and fruit development. Changes in color, shape, size, and time period of each stage in twenty inflorescences of four plants were observed. The period from flower initiation to fruit maturity of $\underline{\mathrm{S}}$. bracteosa took on average 145 days. Flower initiation took on average 16 days, small bud stage occurred in 38 days, large bud phase occurred in 16 days, anthesis stage took on average 5 days and fruit development would complete in 74 days.
\end{abstract}

Keywords: Flowering development, fruiting development, Saurauia bracteosa $D C$

\begin{abstract}
ABSTRAK
Saurauia bracteosa DC. memiliki potensi sebagai obat kanker dan tumor, namun informasi mengenai sistem reproduksinya hingga saat ini belum diketahui. Penelitian ini bertujuan untuk mengetahui tahap perkembangan bunga dan buah $S$. bracteosa. Penelitian dilakukan dengan metode observasi terhadap bunga dan buah $S$. bracteosa meliputi: karakteristik struktur bunga dan tahapan perkembangan bunga sampai buah masak. Perkembangan pembungaan dan pembuahan diklasifikasikan ke dalam lima fase yaitu fase inisiasi, fase kuncup kecil, fase kuncup besar, bunga mekar, dan fase perkembangan buah. Pengamatan dilakukan terhadap perubahan warna, bentuk, ukuran, dan periode waktu dari setiap tahap perkembangan bunga dan buah dari 20 pembungaan pada empat pohon sampel. Hasil penelitian menunjukkan bahwa rata-rata lama pembungaan dan pembuahan spesies $S$. bracteosa mulai awal inisiasi hingga buah masak adalah 145 hari. Durasi yang dibutuhkan untuk setiap fase adalah fase inisiasi 16 hari, fase kuncup kecil 38 hari, fase kuncup besar 16 hari, fase bunga mekar 5 hari, dan fase perkembangan buah dari bunga gugur hingga buah masak 74 hari.
\end{abstract}

Kata kunci: Perkembangan bunga, perkembangan buah, Saurauia bracteosa DC

\section{PENDAHULUAN}

Pirdot (Saurauia bracteosa DC.) merupakan salah satu tumbuhan yang berpotensi sebagai obat tumor dan kanker. Jenis ini tumbuh dan menyebar dari pulau Sumatera hingga Sulawesi.
Ekstrak daun $S$. bracteosa mengandung senyawa fenolik, flavonoid dan tanin yang mempunyai sifat antikanker (Muaja, Koleangan, \& Runtuwene, 2013), antioksidan (Kadji, Runtuwene, \& Citraningtyas, 2013), obat diabetes, dan 
menurunkan kolesterol (Maukar, Runtuwenw, \& Pontoh, 2013)..

Studi tentang kandungan fitokimia $S$. bracteosa telah banyak dipublikasikan (Maukar et al., 2013; Muaja et al., 2013; Kadji et al., 2013). Aspek yang diteliti menyangkut uji toksisitas dan analisis kandungan fitokimia ekstrak daun $S$. bracteosa (Maukar et al., 2013). Aspek budidayanya masih sebatas penelitian dasar tingkat perbenihan (Ali, 2015) dan perbanyakan secara vegetatif (Ali, Tobing, \& Harahap, 2010). Publikasi mengenai aspek perkembangan bunga dan buah dari $S$. bracteosa belum pernah dilaporkan.

Informasi tahapan perkembangan pembungaan dan pembuahan merupakan informasi yang penting bagi perluasan pengetahuan tumbuhan maupun untuk kepentingan perkembangan sains (Jamsari, Yaswendri, \& Kasim, 2007). Pemahaman akan proses perkembangan bunga dan buah juga penting bagi program pemuliaan dan aktivitas hortikultura khususnya pohon-pohon yang dimanfaat-kan buahnya (Engin \& Unal, 2007; Imani \& Mehr-abadi, 2012). Pengamatan terhadap siklus perkembangan bunga hingga buah bisa menjadi acuan terhadap waktu pemanenan (Syamsuwida, Palupi, Siregar, \& Indrawan, 2012) dan dibutuhkan untuk mengatasi persoalanpersoalan yang ber-hubungan dengan produksi buah yang rendah (Camellia, Thohirah, \& Abdullah, 2012). Informasi perkembangan kuncup menjadi calon bunga, waktu perbungaan, dan menjadi buah sangat menentukan keberhasilan sebuah kegiatan perkawinan antar pohon (Baskorowati, Umiyati, Kartikawati, Rimbawanto, \& Susanto, 2008).

Penelitian ini bertujuan untuk mengetahui tahapan perkembangan bunga dan buah $S$. bracteosa yang meliputi karakteristik struktur bunga dan tahapan perkembangan bunga sampai buah masak. Diharapkan hasil penelitian ini dapat memberikan manfaat dalam penentuan masa panen yang berkaitan dengan masak fisiologis buah $S$. bracteosa.

\section{METODOLOGI}

\section{A. Waktu dan Tempat Penelitian}

Penelitian dilakukan di arboretum Balai Penelitian dan Pengembangan Lingkungan Hidup dan Kehutanan (BP2LHK) Aek Nauli pada bulan Juni 2015- April 2016. Arboretum BP2LHK berada di Desa Sibaganding, Kecamatan Girsangsipanganbolon, Kabupaten Simalungun, Propinsi Sumatera Utara, dengan ketinggian tempat $1.200 \mathrm{~m}$ dpl. Kondisi iklim wilayah penelitian tergolong ke dalam daerah beriklim tropis basah, tipe iklim A (berdasarkan Schmidt dan Ferguson) dengan curah hujan tahunan antara 2.199-2.452 $\mathrm{mm}$. Suhu udara berkisar antara $17-29^{\circ} \mathrm{C}$ dan rata-rata kelembaban udara $85 \%$.

\section{B. Metode}

Penelitian dilakukan melalui metode observasi dengan menggunakan pohon $S$. bracteosa sebanyak empat pohon dan diamati lima bunga per pohon. Total sampel sebanyak dua puluh bunga. Tinggi pohon antara 4-5 $\mathrm{m}$ dan diameter 9-12 cm. Selanjutnya dilakukan pengamatan pada stadium perkembangan bunga dan buah didasarkan kepada kriteria yang diguna-kan oleh Jamsari et al. (2007) dengan batasan masing-masing stadium dijelas-kan pada Tabel 1.

Pada masing-masing sampel bunga yang diamati diberi tanda dengan memasang label. Tahapan yang diamati dimulai sejak munculnya tanda-tanda inisiasi bunga yaitu berupa benjolan pada ketiak daun hingga buah masak fisiologis. Pengamatan dilakukan setiap hari dengan mengamati perubahan yang terjadi me-liputi perubahan warna, bentuk dan ukuran, serta mencatat jangka waktu yang dibutuhkan masing-masing tahap. 
Untuk melengkapi data dilakukan pendokumen-tasian struktur dan morfologi bunga dengan menggunakan kamera digital dan mikroskop digital.

\section{HASIL DAN PEMBAHASAN}

\section{A. Hasil}

Hasil penelitian perkembangan bunga dan buah $S$. bracteosa mulai dari inisiasi sampai buah masak tersaji dalam Tabel 2. Waktu yang dibutuhkan fase inisiasi adalah 6-29 hari, diikuti fase kuncup kecil selama 20-53 hari. Fase selanjutnya adalah fase kuncup besar yang berlangsung 11-20 hari. Fase bunga mekar merupakan fase terpendek yaitu 37 hari dan diikuti oleh fase perkembangan buah yang terjadi selama 64-82 hari.

Dari Tabel 2 terlihat bahwa periode terlama dari perkembangan bunga sampai buah pada $S$. bracteosa terjadi pada tahap perkembangan buah dari buah muda hingga buah matang yaitu selama 64-82 hari. Warna kuncup bunga dari satu fase ke fase yang lain tidak mengalami perubahan yang menyolok.

\section{B. Pembahasan}

Tahap awal dari perkembangan bunga adalah proses induksi yaitu suatu tahap yang menyebabkan perubahan fase vegetatif menjadi fase reproduktif (Lizawati, Ichwan, Gusniwati, \& Neliyati, 2013). Tahap ini melibatkan reaksi kimia yang terjadi pada tingkat sel sehingga tidak terdeteksi secara makroskopis sebagaimana yang dilaporkan oleh Mudiana \& Ariyanti (2010) pada per-kembangan bunga Syzygium pycnanthum. Tahap induksi pada $S$. bracteosa tidak teramati secara visual dan baru teramati saat berakhirnya proses induksi. Akhir stadium induksi ditandai dengan mem-bengkak dan membesarnya pangkal calon tunas baru ataupun pada ketiak daun yang kemudian muncul sebagai kuncup bunga. Secara mikroskopik tahap akhir dari stadium induksi menunjukkan perubahan anatomi pada pangkal calon tunas baru yang tampak membesar dan membengkak. Setelah berakhirnya fase induksi, perkembangan bunga dan buah $S$. bracteosa memasuki lima fase berikut:

Tabel (Table) 1. Kriteria perkembangan bunga dan buah S. bracteosa (Criteria for the development of flowers and fruits $\underline{\mathrm{S}}$. bracteosa)

\begin{tabular}{|c|c|c|}
\hline No & Fase (Stage) & Deskripsi (Description) \\
\hline 1. & Inisiasi (Initiation) & $\begin{array}{l}\text { Dimulai sejak kuncup bunga muncul hingga struktur klaster bunga } \\
\text { majemuk muncul (Starting from the emergence of flower buds until the } \\
\text { appearance of cluster structure) }\end{array}$ \\
\hline 2. & $\begin{array}{l}\text { Kuncup kecil } \\
\text { (Small bud) }\end{array}$ & $\begin{array}{l}\text { Mulai munculnya struktur klaster bunga majemuk sampaimahkota bunga } \\
\text { muncul dari bakal buah yang membungkusnya (The onset of the flower } \\
\text { cluster structure until the the appearance of petals) }\end{array}$ \\
\hline 3. & $\begin{array}{l}\text { Kuncup besar } \\
\text { (Large bud) }\end{array}$ & $\begin{array}{l}\text { Dimulai sejak bakal mahkota bunga mulai keluar dari bakal buah sampai } \\
\text { mahkota bunga mulai membuka (Starting from the appearance of petals } \\
\text { until petal start to bloom) }\end{array}$ \\
\hline 4. & $\begin{array}{l}\text { Bunga terbuka } \\
\text { (Anthesis) }\end{array}$ & $\begin{array}{l}\text { Diawali sejak mahkota bunga mulai membuka sampai mahkota bunga } \\
\text { gugur (Starting from blooming petal until petal falls) }\end{array}$ \\
\hline 5. & $\begin{array}{l}\text { Perkembangan buah } \\
\text { (Fruit development) }\end{array}$ & $\begin{array}{l}\text { Sejak mahkota bunga gugur sebagai tanda telah terjadinya pembuahan } \\
\text { sampai buah masak fisiologis (Since the petals fall as the sign of } \\
\text { fertilization until ripe fruit) }\end{array}$ \\
\hline
\end{tabular}

Sumber (Source) : Jamsari et al. (2007) 
Tabel (Table) 2. Tahapan perkembangan pembungaan dan pembuahan S. bracteosa (Developmental stages of flowering and fruiting of $\underline{\mathrm{S}}$. bracteosa)

\begin{tabular}{|c|c|c|c|c|c|c|}
\hline \multirow[t]{2}{*}{ No. } & \multirow[t]{2}{*}{ Fase (Stages) } & \multirow{2}{*}{$\begin{array}{c}\text { Karakter } \\
\text { (Characters) }\end{array}$} & \multicolumn{2}{|c|}{ Ukuran $($ Size $)(\mathrm{mm})$} & \multirow{2}{*}{$\begin{array}{c}\text { Warna } \\
\text { (Color) }\end{array}$} & \multirow{2}{*}{$\begin{array}{c}\text { Periode } \\
\text { (Period) } \\
\text { Hari } \\
(\text { Days }) \\
\end{array}$} \\
\hline & & & $\begin{array}{l}\text { Panjang } \\
\text { (Length) }\end{array}$ & $\begin{array}{l}\text { Diameter } \\
\text { (Diameter) }\end{array}$ & & \\
\hline 1. & $\begin{array}{l}\text { Inisiasi } \\
\text { (Initiation) }\end{array}$ & Kuncup (Bud) & $2,20-20,30$ & & $\begin{array}{l}\text { Hijau semburat merah } \\
\text { tua (Green with } \\
\text { maroon splash) }\end{array}$ & $6-29$ \\
\hline \multirow[t]{2}{*}{2.} & $\begin{array}{l}\text { Kuncup kecil } \\
\text { (Small bud) }\end{array}$ & $\begin{array}{l}\text { Tangkai } \\
\text { bunga } \\
\text { (Pedicels) }\end{array}$ & $9,90-43,70$ & & Hijau (Green) & $20-53$ \\
\hline & & Kuncup (Bud) & $2,53-6,28$ & $2,63-7,37$ & $\begin{array}{l}\text { Hijau semburat putih } \\
\text { (Green with white } \\
\text { splash) }\end{array}$ & \\
\hline \multirow[t]{2}{*}{3.} & $\begin{array}{l}\text { Kuncup besar } \\
\text { (Large bud) }\end{array}$ & $\begin{array}{l}\text { Tangkai } \\
\text { bunga } \\
\text { (Pedicels) }\end{array}$ & $43,70-74,00$ & & Hijau (Green) & $11-20$ \\
\hline & & Kuncup (Bud) & $6,28-9,12$ & $7,37-9,00$ & $\begin{array}{l}\text { Putih dengan kelopak } \\
\text { hijau (White with } \\
\text { green calyx) }\end{array}$ & \\
\hline 4. & $\begin{array}{l}\text { Bunga mekar } \\
\text { (Anthesis) }\end{array}$ & $\begin{array}{l}\text { Bunga } \\
\text { (Flower) }\end{array}$ & $10,60-14,10$ & $16,10-23,70$ & Putih (White) & $3-7$ \\
\hline 5. & $\begin{array}{l}\text { Perkembangan } \\
\text { buah (Fruit } \\
\text { development) }\end{array}$ & Buah (Fruit) & $6,46-13,51$ & $6,66-14,24$ & $\begin{array}{l}\text { Hijau tua hingga } \\
\text { hijau kekuningan } \\
\text { (Dark green to } \\
\text { yellow greeny) }\end{array}$ & $64-82$ \\
\hline
\end{tabular}

\section{Fase inisiasi}

Fase inisiasi merupakan tahap ketika perubahan morfologis menjadi bentuk kuncup reproduktif mulai dapat terdeteksi secara makrokopis untuk pertama kalinya. Fase ini pada $S$. bracteosa ditandai dengan munculnya kuncup bunga pada ketiak daun ataupun pada ujung batang berupa kuncup campuran. Kuncup campuran merupakan kuncup yang berkembang menghasilkan tunas dengan daun dan bunga (Tjitrosoepomo, 2011). Kuncup $S$. bracteosa diselimuti oleh rambut-rambut yang lebat seperti vilt (tomentose), berwarna hijau kemerahan. Pada fase ini secara kasat mata belum terlihat jelas perbedaan antara tangkai bunga dengan bagian bunga lainnya, namun secara mikroskopik telah terlihat perbedaan antara primordial bunga dengan tangkai bunga (Lampiran 1). Struktur beberapa bakal organ kelamin seperti benang sari dan putik belum terbentuk. Struktur bunga majemuk yang didukung oleh daun pelindung (bractea) mulai terlihat di akhir fase inisiasi. Daun pelindung yang ber-jumlah 2-3 helai diselimuti oleh rambut yang tebal berwarna hijau berujung merah.

Panjang bakal bunga dari bagian pangkal tangkai hingga ujung kuncup pada saat awal inisiasi berkisar antara 0,22-0,61 cm dan pada akhir fase berkisar antara 0,56-2,03 cm. Lama waktu inisiasi bunga $S$. bracteosa rata-rata 16 hari dengan standar deviasi 9 hari. Waktu inisiasi yang relatif cepat ditemukan pada kuncup bunga yang muncul di ujung ranting yang biasanya bersamaan dengan munculnya tunas primordial daun, sedangkan waktu insiasi yang relatif lama ditemukan pada kuncup bunga yang muncul di ketiak daun, terutama ketiak 
daun tua. Hal ini terjadi bahwa bakal bunga dapat keluar dari ketiak-ketiak daun yang terletak pada batang utama atau cabang produktif terutama yang masih muda. Jumlah kuncup bunga yang paling banyak berasal dari ketiak daun cabang primer. Kuncup bunga selanjutnya berkembang menjadi bunga dengan struktur bergerombol (klaster) (Lampiran 2). Dalam satu klaster terdapat rata-rata 45 bunga.

\section{Fase kuncup kecil}

Fase inisiasi berakhir dengan terlihatnya secara makroskopik perbedaan antara tangkai bunga dengan bagian yang membentuk bunga. Bunga majemuk $S$. bracteosa pada fase ini semakin jelas terlihat ditutupi oleh seludang bunga. Tangkai bunga dan daun pelindung diselimuti oleh rambut dengan ujung berwarna merah, sedangkan bagian bunga terlihat diselimuti oleh rambutrambut halus berwarna putih.

Fase kuncup kecil rata-rata berlangsung 38 hari dengan standar deviasi 11 hari. Fase ini cukup lama bila dibandingkan fase-fase lainnya dalam perkembangan bunga $S$. bracteosa. Pada fase ini terjadi pemanjangan ibu tangkai bunga yang cukup signifikan yaitu sebesar $3,38 \mathrm{~cm}$. Panjang tangkai pada awal fase rata-rata adalah $0,99 \mathrm{~cm}$ dengan standar deviasi $0,22 \mathrm{~cm}$ dan diakhir fase rata-rata mencapai $4,37 \mathrm{~cm}$ dengan standar deviasi 2,04 cm. Pemanjangan ibu tangkai bunga diikuti oleh penambahan ukuran karena bagianbagian bunga yang ada di dalam-nya semakin berkembang. Penambahan ukuran kuncup menandakan bakal-bakal bunga yang ada di dalam kuncup menampakkan pertumbuhan dan perkembangan (Damaiyani \& Metusala, 2011).

Perkembangan pada fase kuncup kecil terlihat jelas karena bagian bakal bunga sudah mengalami perkembangan. Pada akhir fase ini secara mikroskopis bagian-bagian kelopak, mahkota, benang sari dan bakal putik sudah terlihat jelas meskipun belum sempurna. Kelopak bunga yang berwarna hijau diselimuti oleh rambut berwarna putih. Rambutrambut ini semakin berkurang dengan semakin membesarnya bunga. Bakal buah terlihat terdiri dari lima ruang dengan bakal biji yang berwarna putih kekuningan. Benang sari juga berwarna putih kekuningan. Bakal mahkota terlihat seperti lembaran-lembaran di bawah kelopak bunga (Lampiran 3).

\section{Fase kuncup besar}

Pecahnya kelopak bunga dan mulai munculnya mahkota bunga berwarna putih merupakan tanda berakhirnya fase kuncup kecil dan awal bagi fase kuncup besar. Perhitungan jumlah hari yang dibutuhkan sejak awal inisiasi menuju awal fase kuncup besar adalah 51 hari dengan standar deviasi 3 hari. Fase ini kemudian berlangsung selama 16 hari dengan standar deviasi 3 hari. Selama fase ini pemanjangan tangkai bunga terus berlangsung dengan rata-rata pemanjangan tangkai bunga $4,13 \mathrm{~cm}$. Nilai ini lebih besar bila dibandingkan fase kuncup kecil.

Saat awal fase, mahkota bunga terlihat keluar dari kelopak yang membungkusnya, namun putik dan benang sari masih dibungkus oleh mahkota yang belum mekar. Lembaran-lembaran mahkota terlihat berwarna putih. Tidak terjadi perubahan warna lembaran mahkota dari awal hingga akhir fase. Berbeda bila dibandingkan dengan tanaman surian yakni di awal fase mahkota berwarna hijau keputihan menjadi merah keputihan saat akhir fase (Hidayat, 2010). Pada awal fase terlihat benang sari masih dalam proses perkembangan dan menjadi hampir matang saat akhir fase (Lampiran 4). Kondisi ini menunjukkan bahwa benang sari telah siap untuk menyerbuki putik 
disaat bunga mekar. Bakal buah juga terlihat telah terbentuk dengan sempurna.

\section{Fase bunga terbuka}

Tahap selanjutnya adalah tahap bunga mekar, terjadi rata-rata setelah hari ke-65 dengan standar deviasi 4 hari sejak awal tahap inisiasi. Dibandingkan dengan bunga lengkeng yang membutuhkan waktu 28 hari (Tyas, Setyati, \& Umiyah, 2013), maka bunga $S$. bracteosa membutuhkan waktu dua kali lebih lama. Demikian pula bila dibandingkan dengan tanaman $S$. pycnantum yang berlangsung selama 26-31 hari (Mudiana \& Ariyanti, 2010) .

Bunga mekar sempurna 2-3 hari setelah mulai membukanya mahkota bunga. Rata-rata bunga $S$. bracteosa mengalami fase bunga mekar selama 5 hari dengan standar deviasi 2 hari. Mekarnya bunga $S$. bracteosa didahului dengan terbukanya mahkota kemudian diikuti dengan munculnya putik dari tabung mahkota. Saat awal fase terlihat penumpukan polen di kepala sari dan akhirnya pecah (Lampiran 5).

Ketika bunga mekar, benang sari yang berwarna kuning menarik serangga penyerbuk untuk datang. Aroma, warna dan bentuk bunga merupakan bagian yang atraktif untuk menarik perhatian serangga untuk mengunjungi bunga. Beberapa serangga yang teramati pada saat bunga $S$. bracteosa mekar adalah lebah, semut hitam bersayap, dan kumbang (Lampiran 6). Untuk menentukan serangga yang membantu proses penyerbukan perlu isolasi bunga dan penelitian lebih men-dalam sehingga terbukti serangga mana yang berfungsi sebagai pollinator dan jenis apa yang hanya sekedar berkunjung.

Setelah bunga mengalami pemekaran sempurna, struktur morfologi bunga yang ada dapat bertahan 3-4 hari. Bunga betina Jatropha curcas juga bertahan selama 3-4 hari, sedangkan bunga jantan- nya mekar selama 8-11 hari (Camellia et al., 2012). Bunga S. bracteosa memiliki 5-6 daun bunga yang berwarna putih dengan ukuran yang lebih besar daripada kelopak bunga. Kebanyakan bunga jenis Saurauia memiliki kelopak berwarna hijau dan daun bunga berwarna putih. Pada bagian dasar mahkota melekat tangkai sari yang berjumlah 33-36 buah dengan kepala sari yang berwarna kuning. Di akhir fase bunga mekar terlihat kepala sari sudah terbuka dan benang sari sudah mulai layu dibandingkan saat awal fase. Hal ini dapat digunakan sebagai ciri-ciri bahwa bunga sudah terjadi proses penyerbukan dan fertilisasi (Tyas et al., 2013). Pada bagian putik terlihat serbuk sari telah menempel di kepala putik. Ciri lain dari akhir fase adalah bagian bunga seperti mahkota dan benang sari akan gugur (absisi), sedang-kan daun kelopak dan tangkai putik tetap menempel pada bakal buah. Mahkota tidak mengalami proses pelayuan ataupun perubahan warna sebelum proses absisi sehingga mahkota yang jatuh ke lantai hutan berwarna putih dan terlihat masih segar.

\section{Perkembangan buah}

Fase pembentukan buah dimulai sejak akhir fase bunga terbuka. Hasil pengamatan menunjukkan bahwa fase ini rata-rata terjadi setelah hari ke-70 dengan standar deviasi 4 hari sejak awal inisiasi pembungaan. Proses ini ditandai dengan gugurnya beberapa struktur perhiasan bunga yaitu mahkota dan benang sari, sedangkan tangkai putik tetap tinggal hingga buah masak. Daun kelopak meskipun tetap tinggal, namun tidak menjadi bagian dari buah sejati. Buah mengalami perkembangan dan pematangan rata-rata selama 74 hari dengan standar deviasi 8 hari. Waktu yang dibutuhkan lebih singkat dibandingkan buah surian. Buah surian mengalami perkembangan dari pembuah-an hingga buah matang secara 
fisiologis selama lebih kurang 150 hari (Hidayat, 2010).

Saat awal fase, daun kelopak yang berwarna hijau terlihat menutupi bagian buah yang diselimuti oleh rambut-rambut berwarna putih. Biji telah mulai terbentuk, berwarna kuning pucat. Seiring mem-besarnya buah, kelopak semakin ter-dorong ke bagian pangkal buah. Rambut-rambut putih yang terdapat di bagian kulit buah semakin berkurang dan warna kulit buah menjadi lebih terang. Biji yang terdapat di dalam buah mengalami proses pematangan dengan berubah warna menjadi coklat muda. Buah yang matang berwarna kuning kehijauan, dengan kulit buah yang lunak dan tembus pandang sehingga biji berwarna coklat yang terdapat di dalam buah dapat terlihat dari luar kulit buah (Lampiran 7).

Waktu kumulatif yang dibutuhkan sejak awal inisiasi sampai buah masak rata-rata adalah 145 hari. Waktu yang dibutuhkan $S$. bracteosa lebih lama bila dibandingkan bunga saga. Bunga saga membutuhkan waktu 69-104 hari dengan rata-rata 89 hari (Putri \& Pramono, 2013). Pada tanaman M. cajuputi sub spesies cajuputi terjadi sebaliknya, yaitu waktu yang diperlukan sejak tahap inisiasi bunga hingga buah masak adalah 277 hari (Baskorowati et al., 2008). Siklus reproduktif mindi membutuhkan waktu lebih lama yaitu 6-7 bulan (Syamsuwida et al., 2012) dan kemenyan 8-9 bulan (Syamsuwida, Aminah, Nurochman, Nurkim, \& Sumarni, 2014).

\section{KESIMPULAN DAN SARAN}

\section{A. Kesimpulan}

Rata-rata lama pembungaan dan pembuahan pada spesies $S$. bracteosa sejak awal inisiasi hingga buah masak adalah 145 hari. Rata-rata lama waktu yang dibutuhkan untuk setiap fase fenologi bunga dan pemasakan buah adalah fase inisiasi 16 hari, fase kuncup kecil 38 hari, fase kuncup besar 16 hari, fase bunga mekar 5 hari, dan fase perkembangan buah dari bunga gugur hingga buah masak 74 hari.

\section{B. Saran}

Hasil penelitian ini menjadi dasar untuk mengetahui lama perkembangan bunga dan buah spesies $S$. bracteosa di lokasi yang berbeda sehingga bisa diketahui waktu panen yang tepat untuk menghasilkan buah dan benih yang bermutu.

\section{UCAPAN TERIMA KASIH}

Penulis mengucapkan terima kasih kepada Balai Penelitian dan Pengembangan KLHK yang telah membiayai penelitian ini dan teknisi di Kelompok Peneliti Silvikultur yang telah membantu pengamatan di lapangan.

\section{DAFTAR PUSTAKA}

Ali, C. (2015). Sifat dasar benih pirdot (Saurauia bracteosa DC .) asal Aek Anuli, Sumatera Utara. Dalam Seminar Hasil-hasil Penelitian, 167-175.

Ali, C., Tobing, S.L., \& Harahap, R.M.S. (2010). Pengaruh media dan konsentrasi hormon rootone-F terhadap pertumbuhan stek pucuk dan batang pirdot (Saurauia bracteosa DC.). Dalam Seminar Hasil Penelitian Balai Penelitian Kehutanan Aek Nauli, 218-224.

Baskorowati, I., Umiyati, R., Kartikawati, Rimbawanto, A., \& Susanto, M. (2008). Pembungaan dan pembuahan Melaleuca cajuputi subsp.cajuputi Powell di Kebun Benih Semai Paliyan, Gunung Kidul, Yogyakarta. Pemuliaan Tanaman Hutan, 2(2), 189-202. 
Camellia, N., Thohirah, L.A., \& Abdullah, N.A.P. (2012). Floral biology, flowering behaviour and fruit set development of jatropha curcas 1. in Malaysia. Pertanika Journal of Tropical Agricultural Science, 35(4), 737-748.

Damaiyani, J., \& Metusala, D. . (2011). Fenologi perkembangan bunga Centella asiatica dan studi waktu kematanagn pollen pada berbagai stadia. Berk. Penel. Hayati Edisi Khusus, 7A, 75-78.

Engin, H., \& Unal, A. (2007). Examination of flower bud initiation and differentiation in 'Redhaven' Peach by Using Scanning Electron Microscope. Pakistan Journal of Biological Sciences, 7(10), 1824 1826.

https://doi.org/10.3923/pjbs.2004.18 24.1826

Hidayat, Y. (2010). Perkembangan bunga dan buah pada tegakan benih surian (Toona Sinensis Roem). Perkembangan Bunga Dan Buah Pada Tegakan Benih Surian (Toona Sinensis Roem), Jurnal Agrikultura, 21(1), 13-20.

Imani, A., \& Mehr-abadi, S.M. (2012). Floral differentiation and development in early, middle and late blooming almond cultivars. African Journal of Microb, 6(25), 5301-5305.

Jamsari, Yaswendri, \& Kasim, M. (2007). Fenologi perkembangan bunga dan buah spesies Uncaria gambir. Biodiversitas, 8, 141-146.

Kadji, M.H., Runtuwene, M.R.J., \& Citraningtyas, G. (2013). Uji fitokimia dan aktivitas antioksidan dari ekstrak etanol daun soyogik (Saurauia bracteosa DC). Pharmacon, 5(1), 13-17.
Lizawati, Ichwan, B., Gusniwati, \& Neliyati, Z.M. (2013). Fenologi pertumbuhan vegetatif dan generatif tanaman duku varietas kumpeh pada berbagai umur. Agroekoteknologi, 2(1), 16-26.

Maukar M.A, Runtuwene, M.R.J, \& Pontoh, J. (2013). Analisis kandungan fitokimia dari uji toksisitas ekstrak metanol daun soyogik (Sauraula bracteosa DC ) dengan menggunakan metode maserasi, Ilmiah Sains, 13(2), 99101.

Muaja, A.D., Koleangan, H.S.J., \& Runtuwene, M.R.J. (2013). Uji toksisitas dengan metode BSLT dan analisis kandungan fitokimia ekstrak daun soyogik (Saurauia bracteosa DC) dengan metode Soxhletasi. Journal of Natural Products, 2(2), 115-118.

Mudiana, D., \& Ariyanti, E. (2010). Flower and fruit development of Syzygium pycnanthum Merr. \& L.M. Perry. Biodiversitas, Journal of Biological Diversity, 11(3), 124128.

https://doi.org/10.13057/biodiv/d1 10 304

Putri, K.P., \& Pramono, A.A. (2013). Perkembangan bunga, buah dan keberhasilan reproduksi jenis saga. Penelitian Hutan Tanaman, 10(3), 147-154.

Syamsuwida, D., Aminah, A., Nurochman, Nurkim, \& Sumarni E.B,G.J. (2014). Siklus perkembangan pembungaan dan pembuahan serta pembentukan buah kemenyan (Styrax benzoin) di Aek Nauli. Jurnal Penelitian Hutan Tanaman, 11(2), 89-98.

Syamsuwida, D., Palupi, E.R., Siregar, I.Z., \& Indrawan, A. (2012). Flower initiation, morphology, and developmental stages of flowering- 
Perkembangan Bunga dan Buah Pirdot (Saurauia bracteosa DC.) dl Arboretum Aek Nauli

Cica Ali dan Aam Aminah

fruiting of mindi (Melia azedarach

L). Jurnal Manajemen Hutan

Tropika, 18(1), 10-17.

https://doi.org/10.7226/jtfm.18.1.10

Tjitrosoepomo, G. (2011). Morfologi

Tumbuhan. Yogyakarta: Gadjah Mada University Press.
Tyas, P. S., Setyati, D., \& Umiyah. (2013). Perkembangan pembungaan lengkeng (Dimocarpus longan Lour) "Diamond river." Jurnal Ilmu Dasar, 14(2), 111-120. 
Lampiran (Appendix) 1. Penampilan morfologi dan penampang membujur bunga $S$. bracteosa: (pb) primordia bunga, (tb) tangkai bunga, (dp) daun pelindung pada A) awal fase dan B) akhir fase inisiasi (Morphology and longitudinal section of $\underline{\mathrm{S}}$. bracteosa flower: $(p b)$ flower primordia, (tb) pedicel, (dp) bract, at A) beginning and B) late stadium of initiation phase)
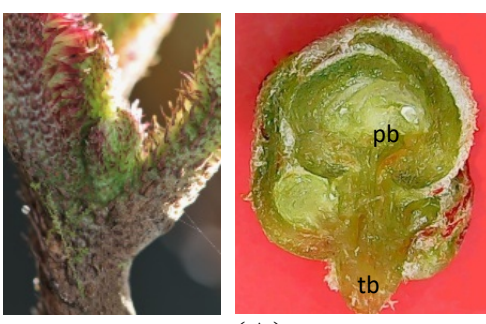

(A)

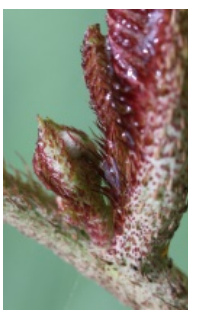

(B)

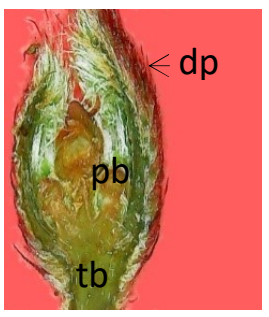

Lampiran (Appendix) 2. Struktur pembungaan S. bracteosa (ㅁ․ bracteosa inflorescense structure)

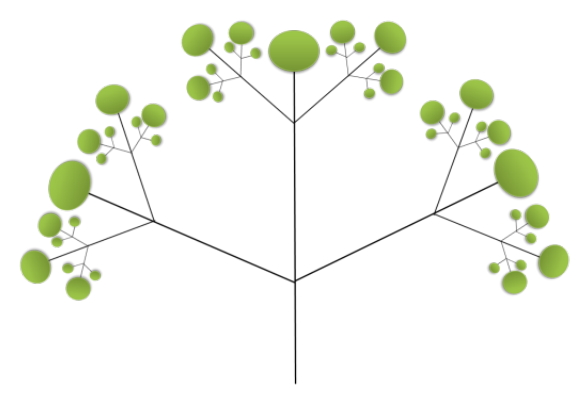

Lampiran (Appendix) 3. (A) Penampilan morfologi bunga S. bracteosa pada fase kuncup kecil; (B dan C) irisan membujur; (D) irisan melintang; (pb) bakal bunga, (tb) tangkai bunga, (dp) daun pelindung, (p) putik, (bs) benang sari, (k) kelopak, (pm) bakal mahkota, (bb) bakal buah. (A) Morphological appearance of flower $\underline{\mathrm{S}}$. bracteosa on small bud phase; ( $B$ and $C$ ) longitudinal and (D) cross section; (pb) flowerprimordia, (tb) peduncle, (dp) bract, (pp) pistil, (bs) stamen), (k) sepal, (pm) petalprimordial, (bb) ovary)

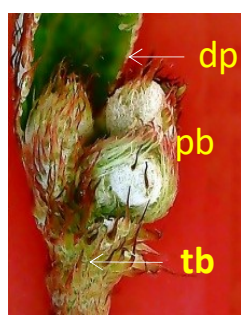

(A)

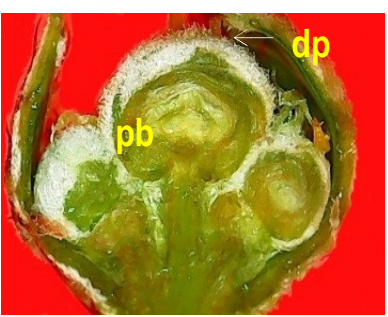

(B)

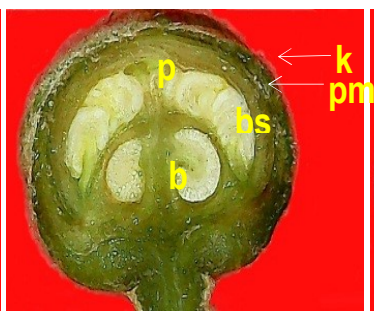

(C)

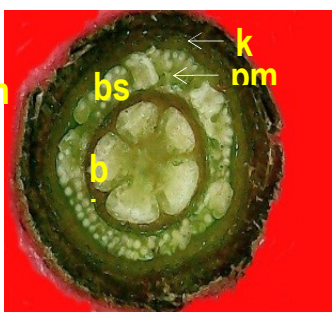

(D) 


\section{Perkembangan Bunga dan Buah Pirdot (Saurauia bracteosa DC.) dl Arboretum Aek Nauli}

Cica Ali dan Aam Aminah

Lampiran (Appendix) 4. Bunga S. bracteosa dan beberapa bagiannya saat memasuki fase kuncup besar, (p) putik, (m) mahkota, (k) kelopak, (bs) benang sari, (tb) tangkai bunga, (bb) bakal buah (Flower of $\underline{\mathrm{S}}$. bracteosa on large bud phase, (p) pistil, (m) petal, ( $k$ ) sepal, (bs) stamen, (tb) peduncle, (bb) ovary)
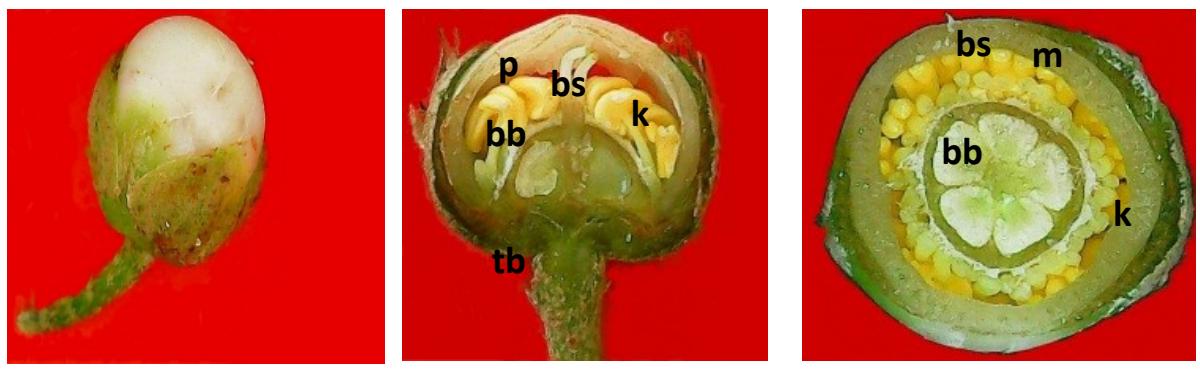

Lampiran (Appendix) 5. Bunga S. bracteosa dan bagiannya saat tahap bunga mekar, (k) kelopak, (m) mahkota, (p) putik, (bb) bakal buah, (bs) benang sari, (kp) kepala putik, (ks) kepala sari, (ss) serbuk sari, (ts) tangkai sari, (tp) tangkai putik (Flower of $\underline{\mathrm{S}}$. bracteosa at anthesis phase, (k) sepal, (m) petal, (p) pistil, (bb) ovary, (bs) stamen, (kp) stigma, (ks) anther, (ss) pollen, (ts) filament, (tp) style)
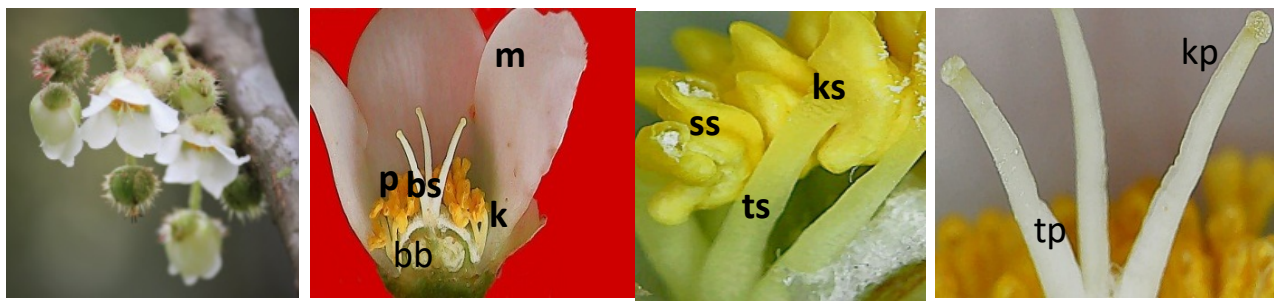

Lampiran (Appendix) 6. Serangga yang teramati saat bunga S. bracteosa mekar (Observed insects when $\underline{\mathrm{S}}$. bracteosa flowers blooms)

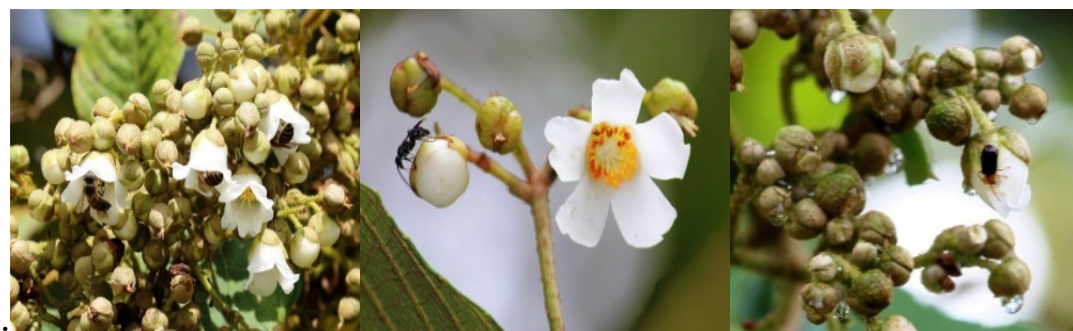


Lampiran (Appendix) 7. Penampilan morfologi dan struktur melintang-membujur buah $S$. bracteosa, (A) buah muda dan (B) buah matang,(b) buah, (k) kelopak, (t) tembuni, (bj) biji, (kb) kulit buah, (tp) tangkai putik (Morphology and longitudinal-cross section of $\underline{\mathrm{S}}$. bracteosa fruit,(A) young fruit and (B) ripe fruit, (b) fructus, (k) sepal, ( $t)$ placenta, (bj) seed, (kb) exocarp, (tp) style)
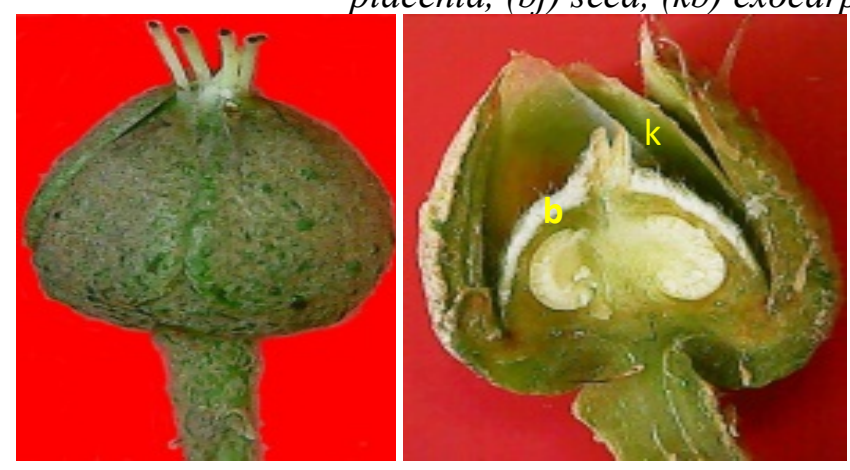

(A)

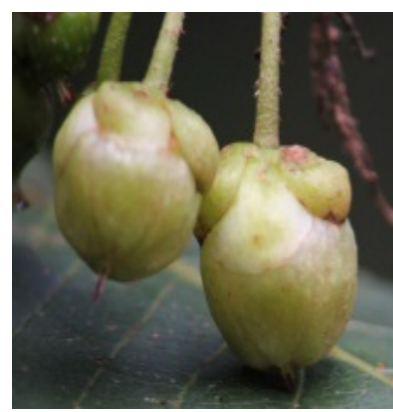

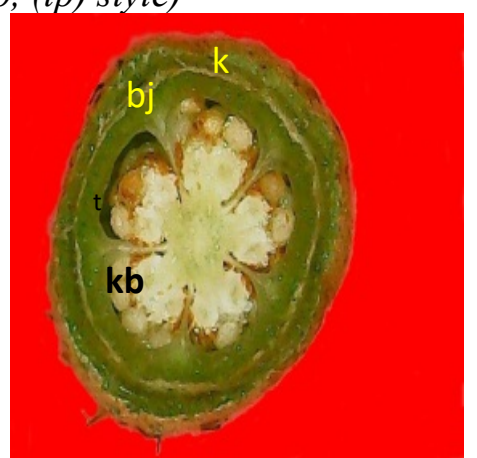

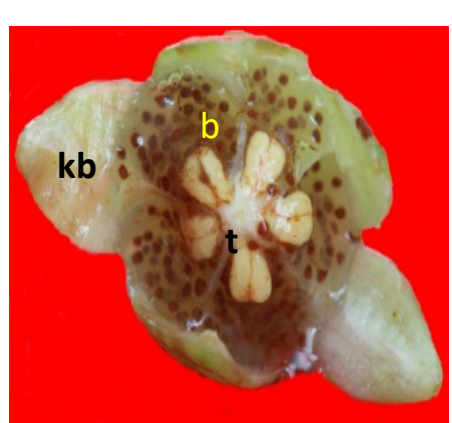

(B) 